УДК 371.3:0004.85

Соколюк Олександра Миколаївна

кандидат педагогічних наук, старший науковий співробітник, провідний науковий співробітник відділу технологій відкритого навчального середовища

Інститут інформаційних технологій і засобів навчання НАПН України, м. Київ, Україна

sokolyuk62@gmail.com

\title{
ВКЛЮЧЕННЯ МЕРЕЖНИХ СОЦІАЛЬНИХ СЕРВІСІВ У ДІЮЧІ МОДЕЛІ ОРГАНІЗАЦЇ̈ НАВЧАННЯ УЧНІВ
}

\begin{abstract}
Анотація. Поєднання інформаційно-комунікаційних технологій 3 педагогічними технологіями навчання сприяє формуванню i розвитку інформаційно-освітнього середовища навчання учнів, а поява і розвиток сервісів мережних технологій дозволяє розширити рамки традиційного освітнього процесу. Освітня практика застосування засобів мережних технологій, зокрема соціальних сервісів, знаходиться на етапі формування. У статті досліджено особливості соціальних сервісів Інтернет 3 точки зору розвитку інформаційно-освітнього середовища як середовища соціальної взаємодії учнів та появи нових способів їх навчально-пізнавальної діяльності. Виділено групи мережних соціальних сервісів та організаційних форм навчання, у яких використання відповідних сервісів $\epsilon$ педагогічно доцільним.
\end{abstract}

Ключові слова: мережні соціальні сервіси; інформаційно-освітнє середовище; інформаційно-комунікаційні технології; навчання.

\section{1. ВСТУП}

Постановка проблеми. Сучасна освіта, як і суспільство в цілому, зазнає значних змін під впливом інформаційно-комунікаційних технологій (IКТ), засобів і технологій інформаційно-комунікаційних мереж (IКМ), зокрема Інтернет, збільшення ролі й обсягів інформації, прояву глобальних взаємозв'язків і взаємозалежностей.

Розвиток комунікаційних систем супроводжується утвердженням нових способів діяльності і самореалізації, що значною мірою проявляється в молодіжному середовищі.

Разом 3 тим, незважаючи на великі можливості глобальних комунікаційних систем i інтерес до нових технологій, в реальній шкільній практиці потенціал інформаційно-комунікаційних мереж реалізується лише частково.

Аналіз останніх досліджень і публікацій. Об'єктивний процес інформатизації усіх сфер людської діяльності призвів до формування нової соціально-економічної формації - інформаційного суспільства 3 подальшим переходом до «суспільств знання».

Ідея переходу від «інформаційного суспільства» до «суспільства знання» була озвучена і закріплена у Всесвітній Доповіді ЮНЕСКО (2005 р.) «До суспільств знання» (Towards knowledge societies) [7].

Поняття інформаційного суспільства, запропонованого і описаного в 1990-х рр. М. Кастельсом, грунтується на численних змінах, що відбулися в світі і пов'язані 3 розвитком засобів поширення інформації і збільшенням іiі потоку, характерного для другої половини XX ст. М. Кастельс стверджує, що «однією із ключових рис інформаціонального суспільства $є$ мережна логіка його базової структури, що й пояснює концепцію «мережного суспільства» [12, с. 9].

Концепція «суспільства знання» спирається на роботи Р. Хатчинса (1968) i Т. Хусена (1974), що запропонували модель суспільства нового типу - «суспільство, 
яке навчається» (learning society) і П. Дракера (1969), який увів поняття «суспільство знань» (knowledge society), у якому найважливіше «навчитися вчитися». Здобуття знань в ньому не обмежується ні стінами освітніх установ (у просторі), ні завершенням освіти (в часі), а стає життєвою необхідністю: «у світі, що стає все більш складним, де кожному протягом життя може знадобитися виконувати різні завдання, стає необхідним продовжувати навчання все життя » [7, с. 59].

Однак, як відзначають дослідники, «становлення концепції «суспільства знання» відбувалося майже одночасно 3 концепцією суспільства інформаційного, але час змістив акценти - і не на користь останнього» [4, с. 6].

У Доповіді ЮНЕСКО розвиваються ідеї структури «мережного суспільства» М. Кастельса, як найбільш адекватної для поширення знань і робиться висновок про те, що «суспільство знання нерозривно пов'язане 3 нематеріальними i мережними суспільствами» [7, с. 47-48]. Розглядаються нові можливості, що відкриваються завдяки приєднанню до освітніх мереж, що дозволяє «публікувати і поширювати в режимі реального часу матеріали за галузями знань 3 урахуванням рівня підготовки учнів $\mathrm{i}$ описом знань, необхідних для засвоєння того чи іншого навчального курсу». Система навчання, пропонована освітніми мережами, більшою мірою враховує попит, який існує на ринку зайнятості та знань [7, с. 98].

Інформаційно-комунікаційні технології, що прискорюють процес отримання та вироблення знання, можуть зіграти чільну роль у створенні освітніх і наукових мереж, «дозволяють збільшити мобільність окремих осіб, а також мобільність знання». Здатність створювати мережі, що об'єднують декілька партнерів, які працюють іноді на дуже великих відстанях один від одного, є засобом забезпечення нової динаміки в системі досліджень. Така координація сьогодні отримала назву «спільної лабораторії» або «співлабораторіi» [7, с. 113].

Співзвучні з цими висновками результати досліджень останніх років. Так у доповіді «Future agendas for global education» (Global Education Futures) [2], присвяченій проектуванню форм і системних інновацій, які допоможуть впоратися з викликами для освіти ХХІ-го століття, прогнозується, що: 1) навчання буде визначатися можливостями доступу до унікальних носіїв компетенцій і спільнотам практик; 2) знання та навички будуть передаватися за рахунок онлайн / офлайн форматів, як в blended learning - в ближній перспективі, а далі - в роботі з повністю автоматизованими системами-наставниками; 3) зміст навчання буде зосереджено не на передачі загальнодоступної інформації і відпрацювання рутинних вправ, а на виробленні складних надпредметних компетенцій, пов'язаних 3 творчим мисленням; 4) відбуватиметься перехід від оцінок досягнень до профілю компетенцій; 5) будуть розвиватися інструменти визначення індивідуального стилю навчання (cognitive traction), темпу роботи над завданнями, залученості учня в навчання та ін.

У звіті "NMC Horizon Report 2015 Higher Education Edition", підготовленому групою експертів міжнародного фонду New media consortium i асоціації розробників інформаційних технологій в освіті Educause, відображено можливий вплив нових технологій, що виникають в освітніх спільнотах по всьому світу, в найближчі п'ять років [3]. Так, до короткострокових перспектив (1-2 роки) автори звіту віднесли зміцнення позицій змішаного навчання i перепланування навчального простору (перетворення просторів навчальних закладів в місця для індивідуального навчання, де зручно працювати зі своїми мобільними пристроями). Середньостроковими перспективами (3-5 років) названі орієнтація на відкриті освітні ресурси. До довгострокових перспектив (5 років і більше) дослідники віднесли розширення співпраці між вузами і зміну культури інновацій (постійне вдосконалення технологій навчання з метою підвищення конкурентоспроможності). 
Експерти компанії Ambient Insight [1], аналізуючи світовий ринок продуктів i послуг IКТ, прогнозують підвищення уваги до використання: а) соціальних мереж $(\mathrm{CM})$; б) SaaS- додатків; в) мобільного навчання.

Необхідно зазначити, що освітні можливості вищезазначених продуктів і послуг IКТ привертають значну увагу, в основному, викладачів вищих навчальних закладів, студентів, науковців.

Так, аналізуючи досвід використання соціальних мереж в освіті, дослідники наводять наступні аргументи на користь їх застосування: задоволення потреб в подіях, досягненнях, визнанні; комфортне і звичне середовище для студента; постійна взаємодія і доступність учасників процесу навчання; можливість групової роботи; спільне створення студентами та викладачами навчального контенту; різноманітність форм комунікації (вікі-сторінки, форуми, опитування, голосування, коментарі, відправка персональних повідомлень, наявність стіни, чату і т.д.); можливість проведення відеоконсультацій; можливість поширювати посилання на навчальнометодичну літературу, наукові статті, обговорювати організаційні питання; широкі демонстраційні можливості (відео-експерименти, лекції, науково-популярні виступи відомих вчених); завдяки СМ викладачі стають доступнішими для студентів; використання СМ викладачами для вирішення професійних завдань [5, с. 626].

Огляд теоретичних і прикладних досліджень, присвячених проблемам еволюції і аналізу соціальних мереж представлений у праці «Соціальні мережі: еволюція, структура, аналіз» [6]. Дослідником виокремлено основні підходи до визначення соціальної мережі, визначено іiі функції; наведена класифікація соціальних мереж в Інтернет-середовищі; приведений короткий опис деяких популярних соціальних мереж, перераховані окремі веб-сервіси і програмні застосування для їх аналізу з проекцією на можливість застосування соціальних мереж у навчанні. Слід зазначити, що автором розроблена програма навчальної дисципліни «Комп’ютерні технології в науці і освіті», до якої включені питання модернізації педагогічного процесу в навчальних закладах із застосуванням IКT (зокрема, особливості використання мережних середовищ, соціальних мереж і Інтернет-сервісів в професійній діяльності сучасного педагога) [6, c.670].

У грунтовному дослідженні «Історико-аналітичний огляд розвитку соціальних мережних технологій і перспектив їх використання у навчанні» було проаналізовано результати сучасних досліджень соціальних мереж у філософських і психологічних науках, соціальних комунікаціях й економіці; окреслено сучасний стан досліджень електронних соціальних мереж і формування практичного досвіду їх використання. Результати досліджень соціальних мереж вивчено й описано автором «з точки зору їх формування в умовах розширення комунікаційного простору глобалізованого соціуму i трансформації старих, а також появи нових практик взаємодії соціальних суб'єктів у різних сферах життєдіяльності суспільства, в освіті зокрема» [21, с. 14]. Але, на думку автора, «процес формування практичного досвіду, активізація спроб використання можливостей соціальних мережних сервісів у педагогічній практиці не супроводжується дидактичним і психолого-педагогічним обгрунтуванням» [21, с. 17].

Отже, проблему організації навчального процесу в середній загальноосвітній школі із застосуванням мережних технологій i сервісів мережі слід визнати актуальною, хоча частка цілеспрямованої організованої навчально-пізнавальної діяльності школярів на їх базі досі невелика.

Мета статті. Дослідити особливості мережних соціальних сервісів. Дослідити проблему включення мережних соціальних сервісів у діючі моделі організації навчання учнів як інструментів соціальної та навчальної взаємодії. 


\section{2. МЕТОДИКА ДОСЛІДЖЕННЯ}

У дослідженні використано: аналіз стану дослідження проблеми у наукових публікаціях; вивчення досвіду використання мережних соціальних сервісів (МСС) у навчальному процесі, організаційних форм навчання, у яких використання МСС $€$ педагогічно доцільним.

Дослідження виконане в межах науково-дослідної роботи «Формування інформаційно-освітнього середовища навчання старшокласників на основі технологій електронних соціальних мереж» (№ ДР 0115U002232).

\section{3. РЕЗУЛЬТАТИ ДОСЛІДЖЕННЯ}

Система освіти, як органічна компонента соціальної системи, у всі часи реагувала на зміни у суспільстві. Тому школа, як базова система освіти, має формувати цілепокладання у відповідності із соціальним замовленням суспільства. Зі змінами соціальної орієнтації суспільства змінюються цілі освіти, перш за все, шкільної. Є. Полат наголошує, що «у даний час цілі освіти у більшості країн цивілізованого світу відображають ідеї гуманістичного напряму у педагогіці, філософії освіти, основні цілі якої направлені на формування і розвиток особистості» [9, с. 7], що, в свою чергу, вимагає принципово нових підходів до організації освітнього процесу, із включення в процес навчання широкого спектра інформаційних ресурсів, із розвитком умінь обробки та подання інформації.

Сучасна система освіти потребує розширення інформаційного поля діяльності для забезпечення комунікації та інформаційної взаємодії між суб'єктами освітнього процесу, для збільшення потужності ресурсної бази пізнання за рахунок більш повного педагогічно виваженого використання електронних освітніх ресурсів. Необхідно враховувати і нові освітні запити сучасних учнів, особливо старшокласників, які відзначаються спрямованістю на навчання активне, практико зорієнтоване, прагматичне, 3 досягненням особистісно-значимого результату. У зв'язку з цим пропонується «перенести в навчальне середовище прийоми і методи середовища соціальних взаємодій, мобільних технологій, віртуальної реальності...Це дозволить створювати в освітньому середовищі нові умови для формування потрібних здатностей і якостей учнів 3 опорою на інформаційні ресурси та мережні комунікації освітніх взаємодій» $[15$, с. 80$]$.

Сучасні педагогічні теорії особистісно-орієтованого, розвиваючого навчання, дитиноцентристська парадигма освіти «висувають на перший план не стільки споживання освітніх послуг формальної освіти, скільки необхідність для учня перебувати в соціальних взаємодіях» [26, с. 110]. На сьогодні процес соціальної взаємодії як «форми соціальних зв'язків, що реалізуються в обміні діяльністю, інформацією, досвідом, здібностями, уміннями, навичками та у взаємному впливі людей» [8, с. 19], під впливом активного розвитку ІКТ та IКМ, відбувається через комп'ютерно орієнтовані інформаційні та комунікаційні канали, технології спілкування.

Одним із сучасних підходів до аналізу проблем соціальної взаємодії виступає підхід М. Кастельса. Виділяючи інформацію «як ресурс, найбільш легкий для проникнення через межі часу і простору» [12, с. 12], він показує зростаючу роль мережних структур, заснованих на процесах інформаційного обміну через глобальні телекомунікаційні системи. На думку М. Кастельса, «мережі - це досить старі форми матеріалізації людської діяльності, проте в наші дні вони знайшли нове життя в результаті перетворення їх в інформаційні мережі, об'єднані Інтернетом». Специфіка 
сучасності приводить до широкого їх розповсюдження та організації на їх основі більшості видів діяльності, перш за все, діяльності зі створення, отримання, передачі інформації [11].

В умовах стрімкого розвитку мережних технологій постає питання про включення мережної освітньої взаємодії в діючі моделі організації навчання. В освітянському середовищі звучить проста і дуже слушна думка про «необхідність розробити такий підхід, який дозволить об'єднати крейду і мережні технології (як інструменти), підручники і ЦОРи (як ресурси), шкільний кабінет і глобальну мережу (як матеріальну базу). Таким чином, нова технологічна база змінює моделі навчання в сучасній школі» [29, с. 165-166]. Така зміна повинна відбуватися з урахуванням наступних (за Є. Патаракіним [20, с. 7-8]) ключових положень психології, педагогіки і філософських аспектів освіти, зокрема учіння, що:

- визначається інструментами і об'єктами, якими користується учень (ідеї інструменталізму Джона Дьюї (діяльність, спрямована на досягнення реального, конкретного результату через використання відповідних інструментів, засобів і технологій - найважливіша складова учіння));

- визначається середовищем, у якому відбувається освоєння нового знання (концепція навчальної мережі (educational network) - «навчальної павутини» I. Ілліча, як середовища для спільного навчання);

- відбувається у спільноті обміну знаннями (ідеї соціального конструкціонізму теорії пізнання, розвиненої П. Бергером і Т. Лукманом; термін "спільнота практики" або "спільнота обміну знаннями" (community of practice) уперше використали Джоуль. Лав і Е. Венгер для того, щоб позначити групу людей, залучених до спільної діяльності);

- відбувається через побудову мережі (основи теорії коннективізму Дж. Сіменса, що розглядає істотні характеристики і специфіку процесу навчання в умовах використання цифрових технологій) .

- $\epsilon$ активним процесом конструювання учнем знання на основі власного досвіду (ідеї конструктивізму, що отримали розвиток у роботах Ж. Піаже, і на основі якої С. Пейпертом розвинена теорія конструкціонізму - філософії навчання, яка додає ідею про те, що люди створюють нове знання особливо ефективно, коли вони залучені до створення особистісно значимих продуктів).

Застосування мережних технологій у навчальному процесі має на увазі «використання освітнього потенціалу як локальних шкільних, так і глобальних мереж, у яких, при взаємодії учасників навчального процесу, виникає соціальна освітня мережа, особливості і можливості якої необхідно вивчати і враховувати» [29, с. 164].

Сучасний рівень розвитку глобальної мережі характеризується стрімким розвитком служб і відповідповідних сервісів - «процесів обслуговування об'єктів Інтернет; сервіси надаються користувачам, програмам, системам, рівням, функціональним блокам» [10, с. 278]. Найбільш поширеними серед них є: зберігання даних, передача повідомлень і блоків даних, електронна і мовна пошта, організація і управління діалогом партнерів, надання з'єднань, проведення сеансів, відео-сервіс.

Серед усієї сукупності представлених у мережі сервісів виділяють "мережні соціальні сервіси" ( $[16 ; 19 ; 20]$ та ін.). Головна ознака соціальних сервісів - «наявність групової взаємодії користувачів в мережі» [20, с. 11] зі зміною ролі користувача - 3 пасивної на активну. У користувача з'являється можливість: перегляду розміщеної на сервісі інформації незалежно від місця знаходження; іiі зберігання як в закритому режимі (доступному тільки авторові), так i відкритому (доступному для усіх користувачів); систематизації даних і організації пошуку за допомогою ключових слів; об'єднання даних в тематичні групи; обговорення наявних матеріалів; аналізу і оцінки 
якості розміщеної на сервісі інформації та ін. [20]. Ця особливість мережних соціальних сервісів (MCC) визначає їх переваги по відношенню до сайтів глобальної мережі, які $\epsilon$ по суті лише сховищами інформації [28, с. 119]. До МСС відносяться: соціальні пошукові системи і народні класифікатори, соціальні мережі, блоги, Wiki, соціальні медіасховища, персональні рекомендаційні сервіси, геоінформаційні сервіси.

Соціальні мережі, блоги, інтернет-спільноти є середовищем, яке пропонує, в першу чергу, нові інформаційні та комунікаційні канали, спеціальні технології спілкування, діяльності, нові способи взаємодії. Відмічають той факт, «що існування в подібному середовищі завжди має на увазі продуктивність, тобто результатом діяльності в соціальній мережі або блозі обов’язково є «продукт»: повідомлення (пост), коментар, відданий голос, рішення «вступити в групу чи ні», «додати в друзі чи ні» i т.д. Важливо і те, що будь-яка діяльність є виключно добровільною, вмотивованою, як на етапі вибору соціальної мережі, так і на етапах щоденних дій користувача» [24].

Важливими є дослідження особливостей соціальних сервісів, що відрізняють їх від сайтів, порталів і серверів глобальної мережі [30]. Серед них виділяють:

1. Організаційні, а саме,

- інтерактивність,

- доступність,

- відкритість,

- взаємодія он-лайн/оф-лайн,

- види взаємодії (вчитель-учень, учень-учень, учень-сервіс),

- децентралізація,

- саморозвиток мережі,

- горизонтальні зв'язки,

- простота використання мережних технологій.

2. Психологічні, а саме,

- сприйняття,

- спільне мислення,

- критичність мислення,

- мотиваційний складник,

- емоційна забарвленість,

- толерантність,

- самовираження,

- самостійність користувача,

- творчий потенціал,

- анонімність,

- добровільність і бажаність контактів.

3. Педагогічні, а саме,

- мультимедійність,

- комунікативність,

- продуктивність,

- індивідуальність,

- активізація пізнавальної, рефлексивної і самостійної діяльності,

- варіативність навчальних завдань,

- планування діяльності,

- розвиток творчої діяльності,

- позаурочна діяльність. 
На основі методу метамоделювання освітнього процесу (соціальний, психологічний і інформаційний підходи) [18] виділено основні групи освітніх функцій мережних сервісів, а саме соціальні, психологічні, інформаційні [28]. До групи соціальних функцій входять функції соціальної взаємодії з комунікативною (обмін інформацією), інтерактивною (взаємодія) i перцептивною (розуміння /оцінка) компонентами. До групи психологічних - мотиваційна, орієнтаційна, інструментальна і контрольно-оціночна компоненти. Інформаційні функції забезпечують створення, накопичення, перетворення інформації, обмін нею, визначення цінності інформації та її відбір.

Зауважимо, що реалізація цих функцій залежить від особливостей організації навчального процесу, які визначаються його дидактичною метою, формою, видом навчальної інформації.

Грунтуючись на результатах досліджень [14; 17; 22; 23; 31;32], можна окреслити групи сервісів, використання яких є доцільним під час: - вивчення нового матеріалу; повторення, узагальнення і систематизації знань учнів; - формування умінь і навичок; контроль навчальних досягнень; - організації самостійної навчальної діяльності; спільної, в тому числі парної, групової, колективної діяльності (табл. 1).

Табличя 1.

\begin{tabular}{|l|l|}
\hline \multicolumn{1}{|c|}{ Призначення } & \multicolumn{1}{|c|}{ Групи сервісів } \\
\hline Вивчення нового матеріалу & $\begin{array}{l}\text { сервіси на технології Wiki-Wiki; } \\
\text { сервіси для зберігання документів (текстових } \\
\text { файлів, презентацій, Google документи); } \\
\text { сервіси зберігання матеріалів різних медіa } \\
\text { форматів. }\end{array}$ \\
\hline сервіси на технології Wiki-Wiki; \\
Повторення, узагальнення і \\
систематизація знань учнів \\
файлів, презентацій, Google документи); \\
сервіси зберігання матеріалів різних медіа \\
форматів; \\
геоінформаційні сервіси; \\
сервіси обміну знаннями.
\end{tabular}




\begin{tabular}{|l|l|}
\hline & форматів; \\
& геоінормаційні сервіси; \\
& $\begin{array}{l}\text { блоги; } \\
\text { сервіси Інтернет-спілкування: } \\
\text { сервіси планування. }\end{array}$ \\
\hline $\begin{array}{l}\text { Організація спільної } \\
\text { діяльності (парної, групової, } \\
\text { колективної) }\end{array}$ & $\begin{array}{l}\text { сервіси спільних документів; } \\
\text { блоги; } \\
\text { сервіси Інтернет-спілкування. }\end{array}$ \\
\hline
\end{tabular}

Вищезазначені особливості та функції МСС дають підстави вважати, що цей інструмент може бути ефективно використаний для організації навчально-пізнавальної діяльності в інформаційно-комунікаційному предметному середовищі навчання учнів [25], як складника інформаційно-освітнього середовища, що $\epsilon$ «частиною, підпростором інформаційного простору, що ситуативно використовує конкретний користувач для розв'язування освітніх задач» [13, с. 9]. I те, що, «соціальні мережі володіють іншими просторово-часовими характеристиками, ніж реальна дійсність» $\mathrm{i}$ домінують в структурі комунікації у сучасної молоді «наштовхує на думку про необхідність формування освітніх середовищ з використанням функціоналу соціальних мереж» [27, с. 41].

Але при формуванні таких середовищ необхідно: уточнити місце мережних соціальних сервісів у системі джерел навчальної інформації; визначити види навчальної діяльності учнів та виявити способи ії дидактичної підтримки; розглянути особливості реалізації форм організації навчальної діяльності із застосуванням сервісів, уточнити систему форм навчальних занять, у рамках яких доцільне використання МСС, розкрити особливості цих форм навчання; уточнити зміст необхідних умінь, навичок, ІКкомпетентності учнів; визначити зміст і методику підготовки учителя до організації навчального процесу із застосуванням МСС [29].

\section{5. ВИСНОВКИ ТА ПЕРСПЕКТИВИ ПОДАЛЬШИХ ДОСЛІДЖЕНЬ}

Проведений аналіз результатів досліджень дозволив: 1) констатувати, що становлення мережної взаємодії в освіті відповідає викликам часу, які визначатимуть тенденції розвитку системи освіти в цілому, і здатне задовольнити потреби кожного суб'єкта цієї взаємодії; 2) засоби соціальних мережних технологій ще не є повноцінним засобом вирішення традиційних проблем навчання, проте вони надають можливості, які вносять зміни в освітянську практику; 3) визначити особливості соціальних сервісів та їх функції; 4) окреслити групи сервісів, використання яких $\epsilon$ доцільним у навчальному процесі; 5) відзначити важливість включення мережної освітньої взаємодії в діючі моделі організації навчання.

Перспективними, на нашу думку, є дослідження, що зорієнтовані на пошук нових способів організації навчально-пізнавальної діяльності учнів засобами мережних технологій та реалізації особистісно-розвиваючої моделі взаємодії учнів і вчителів на основі комунікативної практики соціальних мереж. А нові педагогічні умови, що при цьому виникатимуть можуть стати контекстом для формування та розвитку предметних компетентностей учнів. 


\section{СПИСОК ВИКОРИСТАНИХ ДЖЕРЕЛ}

1. Adkins S. S. The worldwide market for self-paced eLearning products and services: 2011-2016 forecast and analysis [Електронний ресурс] / Sam S. Adkins. - USA : Ambient Insight, 2013. - 27 p. - URL: http://www.ambientinsight.com/Resources/Documents/AmbientInsight-2011-2016-Worldwide-Selfpaced-eLearning-Market-Premium-Overview.pdf

2. Future agendas for global education (Global Education Futures) [ Будущее образования: глобальная повестка [Електронний ресурс] / - URL: http://www.edu2035.org/pdf/GEF.Agenda_ru.pdf

http://cdn.nmc.org/media/2015-nmc-horizon-report-he-RU.pdf

3. NMC horizon report: 2015 Higher education edition [Електронний ресурс]. - Austin : NMC, 2015. - 65 p. - URL: http://cdn.nmc.org/media/2015-nmc-horizon-report-HEEN.pdf

4. Бунина В.Г. От информационного общества к обществам знания: международные документы об управлении в сфере образования / В.Г. Бунина // Право и управление. XXI век. - 2008 - № 2(7), С. $1-11$.

5. Воронкин А. С. Анализ перспектив развития информационно-коммуникационных технологий обучения студентов высших учебных заведений / А. С. Воронкин // Образовательные технологии и общество. 2016. № 3 С.620-636.

6. Воронкин А.С. Социальные сети: эволюция, структура, аналіз / А.С. Воронкин // Образовательные технологии и общество. 2014. №1 С.650-675.

7. Всемирный доклад ЮНЕСКО «К обществам знания» [Електронний ресурс]. - ЮНЕСКО. 2005 г. http://unesdoc.unesco.org/images/0014/001418/141843r.pdf

8. Дворецька Г.В. Соціологія / Г.В. Дворецька. - К.: КНЕУ, 2001. - 286 с.

9. Интернет в гуманитарном образовании: Учеб. пособие для студ. высш. учеб. заведений / Под ред. Е.С. Полат. - М.: Гуманит. изд. центр ВЛАДОС, 2001. - 272 с.

10. Каптерев А.И. Менеджмент знаний : от теории к технологиям : науч.-метод. пособие. / А.И. Каптерев. М. : Либерия-Бибиинформ, 2005. - 296 с.

11. Кастельс М. Гапактика Интернет: Размышления об Интернете, бизнесе и обществе / М. Кастельс; Пер. с англ. А. Матвеева под ред. В. Харитонова. - Екатеринбург: У -Фактория (при участии изд-ва Гуманитарного ун-та), 2004.- 328 с.

12. Кастельс М. Информационная эпоха: экономика, общество и культура / М. Кастельс; пер. с англ.; под науч. ред. О.И. Шкаратана. - М.: ГУ-ВШЭ, 2000. - 608 с.

13. Кремень В.Г., Биков В.Ю. Категорії "простір" і "середовище": особливості модельного подання та освітнього застосування / В.Г. Кремень, В.Ю. Биков // Теорія і практика управління соціальними системами: філософія, психологія, педагогіка, соціологія : наук.- практ. журн. / Харків. держ. політехн. ун-т, Харк. нац. пед. ун-т ім. Г. С. Сковороди, Укр. інж.-пед. акад. - Харків: - 2013. - № 2. - C. 3-16.

14. Кузьмінська О.Г. Учнівська мережева спільнота як середовище набуття компетентностей / О.Г. Кузьмінська // Комп’ютер у школі та сім’ї. - 2011 . - № 6. С. 12- 15.

15. Лаптев В.В. Профессиональная подготовка в условиях электронной сетевой среды / В.В. Лаптев, Т.Н. Носкова // Высшее образование в России. 2013, № 2, с. 79-83.

16. Леонтьев В.П. Мобильный Интернет. Компьютерная академия на дому / В.П. Леонтьев. - М.: ОЛМА Медиа Групп, 2008. - 149 с.

17. Литвинова С.Г. Корпоративна електронна соціальна мережа Yammer як складова хмаро орієнтованого навчального середовища загальноосвітнього навчального закладу / С. Г. Литвинова // Наукові записки. - Випуск 9. - Серія: Проблеми методики фізико- математичної і технологічної освіти. Частина 2. - Кіровоград: РВВ КДПУ ім.В.Винниченка, 2016. - С. 197-203.

18. Оспенникова Е. В. Развитие самостоятельности школьников в учении в условиях обновления информационной культуры общества : моногр. : в 2 ч. Ч. 1. Моделирование информационнообразовательной среды учения / Е. В. Оспенникова. - Перм. гос. пед. ун-т. Пермь, 2003

19. Патаракин Е. Д., Ярмахов Б. Б. Личное учебное пространство ученика в сети электронных коммуникаций / Е. Д. Патаракин, Б. Б. Ярмахов // Шк. технологии : науч. - практ. журн. - 2009. - N 4. - С. 88-93.

20. Патаракин Е.Д. Социальные сервисы Веб 2.0 в помощь учителю (Учебно-методическое пособие) / Е.Д. Патаракин. - 2-е изд., испр. - М: Интуит.ру, 2007. - 64 с.

21. Пінчук О. П. Історико-аналітичний огляд розвитку соціальних мережних технологій і перспектив їх використання у навчанні / О. П. Пінчук // Інформаційні технології і засоби навчання, 2015, Том 48, №4, c. 14-34.

22. Проценко Г.О. Веб 2.0 - нові можливості Інтеренту / Г.О. Проценко // Комп’ютер у школі та сім’ї. - 2007. - № 7. C. 15-19. 
23. Проценко Г.О. Як навчати та вивчати інформатику в сучасних умовах? / Г.О.Проценко // Комп’ютер у школі та сім’ї. - 2010 . - № 2. С. 31- 33.

24. Скрипкина Ю.В. Новые подходы к развитию коммуникативных компетентностей учащихся: образовательный потенциал социальных сетей и блогов [Електронний ресурс] / Ю.В. Скрипкина // Интернет-журнал "Эйдос".- 2011. - №10. http://eidos.ru/journal/2011/1023-09.htm

25. Соколюк О.М. Особливості формування інформаційно-комунікаційного середовища навчання фізики / О.М. Соколюк // Наукові записки. - Випуск 9. - Серія: Проблеми методики фізикоматематичної ітехнологічної освіти. Частина 1 . - Кіровоград: РВВ КДПУ ім. В.Винниченка. 2016 - c.264, С. 166-173.

26. Стародубцев В.А. Социальные медиа в персонализированной образовательной среде / В.А.Стародубцев // Высшее образование в России : науч.- педагогич. журнал. - 2012. - N 4. - С. 108-113.

27. Шалимов А.Б. Социальные сети как современная образовательная среда / А.Б. Шалимов // «Дискуссия» Ежемесячный научный журнал. - 2013. - № 11 (41). - С. 37-42.

28. Яковлева И. В., Оспенникова Е. В. Образовательное значение сетевых социальных сервисов / И. В. Яковлева, Е. В. Оспенникова // Педагогическое образование в России. - 2012.- № 5. - С. 118-121.

29. Яковлева И.В. Методические аспекты модели обучения физике с применением сетевых социальных сервисов/ И. В. Яковлева // Педагогическое образование в России. - 2014. - № 2. - С. 226-230.

30. Яковлева И.В. Сетевые сервисы и проблема их использования в учебном процессе в средней общеобразовательной школе сервисов / И.В. Яковлева // Вестник ПГПУ. Серия «Информационные компьютерные технологии в образовании». - Пермь: ПГПУ, 2009. - Вып. 5. - С. 159-178.

31. Яковлева И.В. Сетевые социальные сервисы как новое средство в работе учителя / И.В. Яковлева // Информационные технологии в образовании. XIX Международная конференция-выставка: Сборник трудов в 3 частях.Ч. III. - М.: МИФИ, 2009. - 112 с.

32. Яцишин А. В. Застосування віртуальних соціальних мереж для потреб загальної середньої освіти / А.В.Яцишин // Інформаційні технології в освіті. - 2014. - № 19. - С. 119-126.

Матеріал надійшов до редакиї 12.10.2016 p.

\title{
ВКЛЮЧЕНИЕ СЕТЕВЫХ СОЦИАЛЬНЫХ СЕРВИСОВ В ДЕЙСТВУЮЩИЕ МОДЕЛИ ОРГАНИЗАЦИИ ОБУЧЕНИЯ УЧАЩИХСЯ
}

\author{
Соколюк Александра Николаевна \\ кандидат педагогических наук, старший научный сотрудник, \\ ведущий научный сотрудник отдела технологий открытой учебной среды \\ Институт информационных технологий и средств обучения НАПН Украины, г. Киев, Украина. \\ sokolyuk62@gmail.com
}

\begin{abstract}
Аннотация. Сочетание информационно-коммуникационных технологий с педагогическими технологиями обучения способствует формированию и развитию информационнообразовательной среды обучения учащихся, а появление и развитие сервисов сетевых технологий позволяет расширить рамки традиционного образовательного процесса. Образовательная практика применения средств сетевых технологий, в частности социальных сервисов, находится на этапе формирования. В статье исследованы функциональные особенности социальных сервисов Интернет с точки зрения развития информационно-образовательной среды как среды социального взаимодействия учащихся и появления новых способов их учебно-познавательной деятельности. Выделены группы сетевых социальных сервисов и организационных форм обучения, в которых использование соответствующих сервисов является педагогически целесообразным.
\end{abstract}

Ключевые слова: сетевые социальные сервисы; информационно-образовательная среда; информационно-коммуникационные технологии; обучение. 


\title{
INCLUSION OF SOCIAL NETWORKING SERVICES IN THE EXISTING MODEL OF ORGANIZATION OF STUDENTS' LEARNING
}

\section{Oleksandra M. Sokolyuk}

$\mathrm{PhD}$ (in Pedagogics), senior researcher, senior researcher of the Department of Technology of Open Learning Environment Institute of Information Technologies and Learning Tools of NAES of Ukraine, Kyiv, Ukraine sokolyuk62@gmail.com

\begin{abstract}
The combination of ICT with pedagogical training technologies promotes to the formation and development of information and educational environment of students' learning, as well as the appearance and development of services of network technologies allows to expand the traditional educational process. Educational practice of networking tools usage, such as social services, is at the stage of formation. In the article the functional features of social Internet services in the context of the information and educational environment development as an environment of social interaction between students and appearance of new ways of their educational and cognitive activities have been investigated. There are highlighted the groups of social networking services and organizational forms of teaching, in which the use of the relevant services is a pedagogically appropriate.
\end{abstract}

Keywords: network social services; information-educational environment; information and communication technologies; training.

\section{REFERENCES (TRANSLATED AND TRANSLITERATED)}

1. Adkins S. S. The worldwide market for self-paced eLearning products and services: 2011-2016 forecast and analysis [online] / Sam S. Adkins. - USA : Ambient Insight, 2013.-27p.-Available from: http://www.ambientinsight.com/Resources/Documents/AmbientInsight-2011-2016-Worldwide-Selfpaced-eLearning-Market-Premium-Overview.pdf (in English).

2. Future agendas for global education (Global Education Futures) [online] / Budushhee obrazovanija: global'naja povestka - Available from: http://www.edu2035.org/pdf/GEF.Agenda_ru.pdf

3. NMC horizon report: 2015 Higher education edition [online]. - Austin : NMC, 2015. - 65 p. - Available from: http://cdn.nmc.org/media/2015-nmc-horizon-report-HEEN.pdf (in English).

4. Bunina V.G. From Information Society to Knowledge Societies: international documents on the management of education / V.G. Bunina // Pravo i upravlenie. XXI vek. - 2008 - № 2 (7), P. 1-11 (in Russian).

5. Voronkin A.S. Analysis of the prospects for the development of information and communication technologies of training of students of higher educational institutions / A.S. Voronkin // Obrazovatel'nye tehnologii i obshhestvo. 2016. № 3, P. 620-636 (in Russian).

6. Voronkin A.S. Social Networks: evolution, structure analysis / A.S. Voronkin // Obrazovatel'nye tehnologii i obshhestvo. 2014. №1, P. 650-675 (in Russian).

7. UNESCO World Report "Towards Knowledge Societies" [online]. - UNESCO. 2005. - Available from: http://unesdoc.unesco.org/images/0014/001418/141843r.pdf (in Russian).

8. Dvoretska H.V. Sociology / H.V. Dvoretska. - K.: KNEU, 2001. - 286 p. (in Ukrainian).

9. Internet in arts education: Textbook. allowance for students. Executive. Proc. institutions / Pod red. E.S. Polat. - M.: Gumanit. izd. centr VLADOS, 2001. - 272 p. (in Russian).

10. Kapterev A.I. Knowledge Management: from theory to technology: scientific-method. allowance. / A.I. Kapterev. M: Liberija-Bibiinform, 2005. - 296 p. (in Russian).

11. Kastel's M. Galaxy Internet: Reflections on the Internet, Business and Society / M. Kastel's; Per. s angl. A. Matveeva nod red. V. Haritonova. - Ekaterinburg: U -Faktorija (nri uchastii izd-va Gumanitarnogo unta), 2004.- 328 p. (in Russian).

12. Kastel's M. The Information Age: Economy, Society and Culture / M. Kastel's; per. s angl; pod nauch. red. O.I. Shkaratana. - M.: GU-VShJe, 2000. - 608 p. (in Russian).

13. Kremen V.H., Bykov V.Yu. Categories "space" and "environment": features of model representation and educational use / V.H. Kremen, V.Yu. Bykov // Teoriia i praktyka upravlinnia sotsialnymy systemamy: filosofiia, psykholohiia, pedahohika, sotsiolohiia : nauk.- prakt. zhurn. / Kharkiv. derzh. politekhn. un-t, Khark. nats. ped. un-t im. H. S. Skovorody, Ukr. inzh.-ped. akad. - Kharkiv: - 2013. - № 2. - P. 3-16 (in Ukrainian). 
14. Kuzminska O.H. Pupils online community as an environment entry competences / O.H. Kuzminska // Kompiuter u shkoli ta simi. - 2011 . - № 6. P. 12- 15 (in Ukrainian).

15. Laptev V.V. Training in the electronic network environment / V.V. Laptev, T.N. Noskova // Vysshee obrazovanie v Rossii. 2013, № 2, P. 79-83 (in Russian).

16. Leont'ev V.P. Mobile Internet. Computer Academy at home / V.P. Leont'ev. - M.: OLMA Media Grupp, 2008. - 149 p. (in Russian).

17. Lytvynova S.H. Corporate social network Yammer electronic component as a cloud-based learning environment educational institution / S.H. Lytvynova // Naukovi zapysky. - Vypusk 9. - Seriia: Problemy metodyky fizyko - matematychnoi i tekhnolohichnoi osvity. Chastyna 2. - Kirovohrad: RVV KDPU im.V.Vynnychenka, 2016. - P. 197-203 (in Ukrainian).

18. Ospennikova E.V. The development of school autonomy in the teaching of updating information in a culture of a society: monograph. : In 2 hours Part 1. Modeling of educational environment teaching. / E.V. Ospennikova. - Perm. gos. ped. un-t. Perm', 2003(in Russian).

19. Patarakin E.D., Jarmahov B.B. Private student educational space in the electronic communications network / E.D. Patarakin, B.B. Jarmahov // Shk. tehnologii : nauch. - prakt. zhurn. - 2009. - N 4. - P. 8893 (in Russian).

20. Patarakin E.D. Social services of Web 2.0 to help the teacher (teaching manual)/ E.D. Patarakin. - 2-e izd., ispr. - M: Intuit.ru, 2007. - 64 p. (in Russian).

21. Pinchuk O.P. Historical and analytical review of social networking technologies and prospects of their use in education / O.P. Pinchuk // Informatsiini tekhnolohii i zasoby navchannia, 2015, Tom 48, №4, P. 14-34 (in Ukrainian).

22. Protsenko H.O. Web 2.0 - the new power of the Internet / H.O. Protsenko // Kompiuter u shkoli ta simi. 2007. - № 7., P. 15-19 (in Ukrainian).

23. Protsenko H.O. How to teach and learn science in modern conditions? / H.O. Protsenko // Kompiuter u shkoli ta simi - 2010 . - № 2. P. 31- 33 (in Ukrainian).

24. Skripkina Ju.V. New approaches to the development of communicative competence of students: educational potential of social networks and blogs [online] / Ju.V. Skripkina // Internet-zhurnal "Jejdos".2011. - № 10. - Available from: http://eidos.ru/journal/2011/1023-09.htm (in Russian).

25. Sokoliuk O.M. Features of formation of information-communication environment of teaching physics / O.M. Sokoliuk // Naukovi zapysky. - Vypusk 9. - Seriia: Problemy metodyky fizyko-matematychnoi i tekhnolohichnoi osvity. Chastyna 1 . - Kirovohrad: RVV KDPU im. V.Vynnychenka, 2016 - 264 p., P. 166-173 (in Ukrainian).

26. Starodubcev V.A. Social media in a personalized learning environment / V.A.Starodubcev // Vysshee obrazovanie v Rossii : nauch.- pedagogich. Zhurnal. - 2012. - N 4. - P. 108-113. (in Russian).

27. Shalimov A.B. Social networks as a modern educational environment / A.B. Shalimov // «Diskussija» Ezhemesjachnyj nauchnyj zhurnal. - 2013. - № 11 (41). - P. 37-42 (in Russian).

28. Jakovleva I.V., Ospennikova E.V. Educational value of the network of social services / I.V. Jakovleva, E.V. Ospennikova // Pedagogicheskoe obrazovanie v Rossii. 2012. № 5. P. 118-121 (in Russian).

29. Jakovleva I.V. Methodical aspects of physics teaching model, using the network of social services / I.V. Jakovleva // Pedagogicheskoe obrazovanie v Rossii.2014. № 2. P. 226-230 (in Russian).

30. Jakovleva I.V. Network services and the problem of their use in the educational process in secondary school services / .V. Jakovleva // Vestnik PGPU. Serija «Informacionnye komp'juternye tehnologii v obrazovanii». - Perm': PGPU, 2009. - Вып. 5. - P. 159-178 (in Russian).

31. Jakovleva I.V. Networking social services as a new tool in the teacher's work / I.V. Jakovleva // Informacionnye tehnologii v obrazovanii. XIX Mezhdunarodnaja konferencija-vystavka: Sbornik trudov v 3 chastjah.Ch. III. - M.: MIFI, 2009 (in Russian).

32. Yatsyshyn A.V. The use of virtual social networks for the purpose of secondary education / A.V.Yatsyshyn // Informatsiini tekhnolohii v osviti. - 2014. - № 19. - P. 119-126 (in Ukrainian).

Conflict of interest. The author has declared no conflict of interest.

\section{$(\mathrm{CC})$ BY-NC-SA}

This work is licensed under Creative Commons Attribution-NonCommercial-ShareAlike 4.0 International License. 